\title{
Physiological reorganization in the hypotrich ciliate Apoamphisiella vernalis (Protista, Ciliophora, Hypotricha)
}

\author{
Larissa A. M. de Castro', Inácio D. da Silva-Neto², Thiago da S. Paiva ${ }^{1,3}$
}

\begin{abstract}
1. Laboratório de Biologia Molecular "Francisco Mauro Salzano", Instituto de Ciências Biológicas, Universidade Federal do Pará, Belém, PA, Brazil. (tpaiva@biologia.ufri.br) 2. Laboratório de Protistologia, Departamento de Zoologia, Instituto de Biologia, CCS, Universidade Federal do Rio de Janeiro, Rio de Janeiro, RJ, Brazil. 3. Laboratório de Protistologia Evolutiva, Instituto de Biociências, Universidade de São Paulo, São Paulo, SP, Brazil.
\end{abstract}

Received 15 January 2016

Accepted 7 December 2016

DOI: $10.1590 / 1678-4766 e 2017012$

\begin{abstract}
Physiological reorganization is described for the first time for the hypotrich ciliate genus Apoamphisiella Foissner, 1997, based on a population of $A$. vernalis (Stokes, 1887) Berger, 2006 collected from an eutrophic pond in the state of Minas Gerais, Brazil. Stomatogenesis is epiapokinetal, and the cirral pattern reorganizes from six typical fronto-ventral-transverse primordia, plus at least one short primordium located between IV and V. Primordia I and II originate from disaggregating undulating membranes and buccal cirrus, respectively; primordium III originates from left frontoventral cirrus plus a streak of basal bodies extending from the anterior end of oral primordium; primordium IV and the short extra primordia are formed from basal bodies perhaps associated to the posterior end of III plus the disaggregation of anteriormost cirri of the left ventral row. Primordia V and VI arise within the right ventral row as a single streak, splitting to form the two primordia. Marginal primordia develop initially within the pre-existent marginal rows, continuing to reorganize outside, pushing the old marginal cirri leftwards. Two dorsomarginal kineties develop associated to the right marginal row primordium. Dorsal ciliature also reorganizes from within the pre-existent dorsal kineties. The two macronuclear nodules approach each in middle reorganizers, briefly touching each other. At least one micronucleus undergo division. The process of physiological reorganization in $A$. vernalis resembles that of the North American Paraurostyla weissei complex representative, and along with features of the interphase morphology, indicate that Apoamphisiella belongs or is related to the Cyrtohymena-Paraurostyla group, within the Dorsomarginalia.
\end{abstract}

KEYWORDS. Atlantic Forest, Dorsomarginalia, morphogenesis, ontogeny, Spirotrichea.

The Hypotricha (= Stichotrichia sensu Small \& Lynn, 1985) exhibit an astounding variety of ontogenetic processes that originate their highly diverse ciliature patterns (FoISSNER, 1996; FOISSNER et al., 2002; LYNN, 2008). Investigation of ontogeny in hypotrichs is thus of major importance for elucidating their life cycles and to explain how the ciliature patterns develop and organize, facilitating detection of homologies and convergences (e.g. Jerka-Dziadosz, 1965, 1972; Jerka-Dziadosz \& Frankel, 1969; Borror, 1979; Fleury, 1983; Eigner, 1995, 1997, 1999, 2001; EIGNER \& FoISSNER, 1992, 1993, 1994; Berger \& Foissner, 1997; Paiva \& Silva-Neto, 2007, 2009; Siqueira-Castro et al., 2009; De Castro et al., 2016). Zou \& NG (1991) consider physiological reorganization as an ontogenetic process secondarily derived from divisional morphogenesis. It is responsible for renewing a complete conjunct of ciliary elements in intact, non-dividing individuals (GRIMES \& ADLER, 1978). According to BERGER (1999), physiological reorganization usually occurs in response to unfavorable environmental (or culture) conditions, such as starvation or other more subtle changes in the medium. Likewise, very similar reorganizational processes happen to reestablish the normal ciliature after conjugation and excystment events take place, and to regenerate the ciliature after physical trauma (e.g. DembowsKa, 1925; 1938; 1939; NG, 1990; Kamra \& SAPRA, 1991; Zou \& NG, 1991; FrontCZACK-BANIEWICZ \& JeRKA-DZIADOSZ, 1992).

In the present study, we describe, for the first time, stages of physiological reorganization in the hypotrich genus Apoamphisiella Foissner, 1997, based on a strain of Apoamphisiella vernalis (Stokes, 1887) Berger, 2006, from an eutrophic pond in the Atlantic Forest in the state of Minas Gerais, Brazil. The origins of the various elements of the ciliature are traced from ontogeny during physiological reorganization, and results are discussed in comparison with the literature on supposedly related species.

\section{MATERIAL AND METHODS}

Specimens of Apoamphisiella vernalis were obtained from limnetic cultures enriched with crushed rice grains, made using water with sediments collected from a shallow eutrophic pond in the state of Minas Gerais, Brazil, in November of 2002 (approximate geographic coordinates: 21 $\left.{ }^{\circ} 59^{\prime} 36.4^{\prime \prime} \mathrm{S}, 4^{\circ} 57^{\prime} 17.7^{\prime \prime} \mathrm{W}\right)$. Specimens were identified using standard light and electron microscopy techniques commonly used for ciliate taxonomy, which included bright- 
field, differential interference contrast microscopy, scanning electron microscopy and protargol-impregnation (DRAGESCO \& DragesCo-KernÉIS, 1985; DieCKMANN, 1995; DA SILVANeTO et al., 2012). The interphase (non-dividing) cells of this strain were studied in detail by PAIVA et al. (2014), thus the reader is referred to that work and the original description by STOKEs (1887) for the general morphology of $A$. vernalis.

To study physiological reorganization, specimens from near starving cultures of approximately two to three weeks old were fixed Bouin's fluid and impregnated with protargol, following DiECKMANN (1995). Specimens were then mounted in permanent slides and analyzed under bright field microscopy at 500-1,000x. Scale bars are included in the photographs when necessary (FoISSNER \& XU, 2006). Terminology follows WICKLOW (1982) (e.g. "procirri" to refer to immature cirri), Berger (1999, 2006, 2008, 2011) and PAiva et al. (2014); primordia numbering is based on WALLENGREN (1900) and De CASTRo et al. (2016). Voucher slides are deposited in the collection of Laboratório de Protistologia, Instituto de Biologia, Universidade Federal do Rio de Janeiro.

\section{RESULTS}

Physiological reorganization in Apoamphisiella vernalis begins with the formation of an elongated, likely epiapoknetal, oral primordium, which originates de novo in the space between the left marginal and left ventral cirral rows. Such primordium is slender and slightly curved rightwards anteriorly. At its posterior region, there are small patches of basal bodies, suggesting the oral primordium arises from multiple points (Fig. 1). The oral primordium then becomes progressively elongated, forming a short anterior projection and growing slender posteriad (Figs 2, 3). Next, it becomes shorter and clavate, and then commences to produce new adoral membranelles, which will replace approximately half of the old lapel (Figs 4, 5). At the anterior region of body, the paroral and endoral membranes simultaneously dissociate. Starting distally, the disaggregation of basal bodies moves posteriad until both membranes form primordium I. The fronto-ventral-transverse (FVT) primordium II originates from the disaggregation of the buccal cirrus, and primordium III from a long streak that proliferates anteriad from the anterior projection of oral primordium, fusing to the dissociating left frontoventral cirrus. Such long streak possibly contributes also to primordium II. At this stage, a streak of basal bodies which precedes primordia V and VI, grows within the right ventral row (Fig. 4). Primordia IV and IV, arise likely associated with basal bodies near the posterior region of III, with participation of one or two anteriormost cirri from the left marginal row. As primordium II grows posteriad, the five streaks form a fan-shaped structure. The right marginal primordium is already visible at this stage, growing initially within the original structure. Meanwhile, the streak of basal bodies within the right
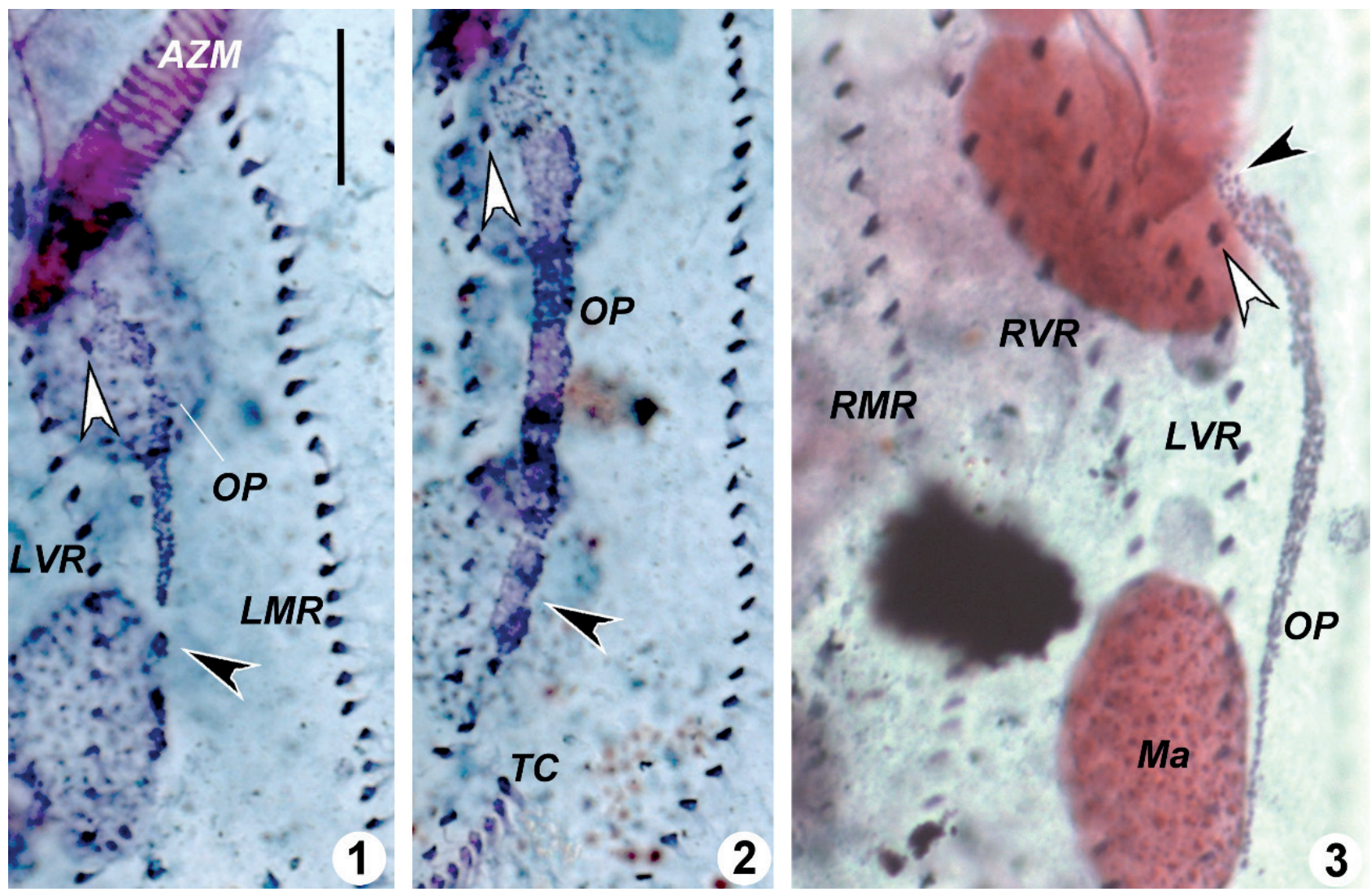

Figs 1-3. Ventral side of early reorganizers, after protargol-impregnation. Figs 1, 2. Epiapokinetal stomatogenesis. Notice some discontinuities in the oral primordium (black arrowheads). Fig. 3. Oral primordium becomes curved to the right and forms an anterior projection (black arrowhead). The white arrowheads mark the postperistomal cirrus, which was not yet resorbed. (AZM, adoral zone of membranelles; LMR, left marginal cirral row; LVR, left ventral cirral row; Ma, macronuclear nodule; OP, oral primordium; RMR, right marginal cirral row; RVR, right ventral cirral row). Scale bar $=20 \mu \mathrm{m}$. 

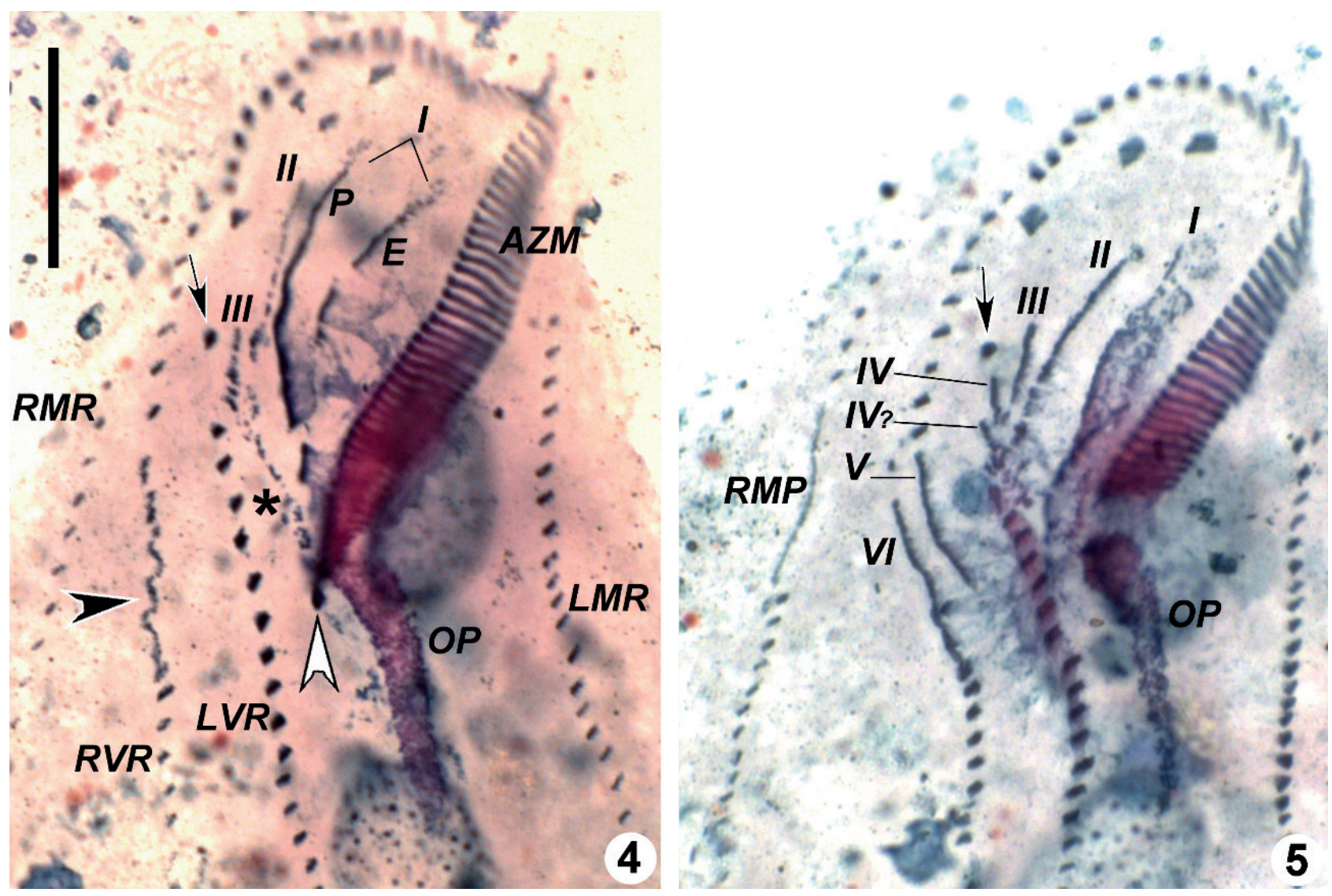

Figs 4, 5. Ventral side of early-to-middle reorganizers, after protargol impregnation. Fig. 4. Early development of primordia I-III. Black arrowhead shows the streak of basal bodies which will form primordia IV and V; white arrowhead shows the postperistomal cirrus. Notice a streak of basal bodies originating from anterior end of oral primordium (asterisk), which contributes to the formation of primordium III. Fig. 5. Early development of primordia IV-VI and right marginal primordium. The arrows point to the right frontoventral cirrus. Fronto-ventral-transverse primordia numbered in romans. (IV, short primordia possibly related to IV; AZM, adoral zone of membranelles; E, endoral; LMR, left marginal cirral row; LVR, left ventral cirral row; OP, oral primordium; P, paroral; RMP, right marginal primordium; RMR, right marginal cirral row; RVR, right ventral cirral row). Scale bar $=20 \mu \mathrm{m}$.

ventral row splits into primordia V and VI (Fig. 5).

In middle-reorganizers, the postperistomal cirrus have been resorbed, and possibly incorporated in the differentiating oral primordium. The right frontoventral cirrus may be resorbed in middle reorganizers or retained until late stages. The left marginal primordium originates at this stage, similarly to the primordium for the right marginal row. Both right and left marginal primordia elongate posteriad, outside and to right of the old structures, pushing them leftwards. Simultaneously, there appear some short basal body streaks continuous with the posterior region of the fan-shaped cluster of FVT primordia, located between IV and V, and forming a ladderized pattern. At this stage, the left frontal procirrus begins to differentiate rightwards from the distal end of the undulating membranes primordium, and the basal bodies of the oral primordium organize into new adoral membranelles (Figs 6, 7). As reorganization proceeds, the FVT cirral streaks begin to differentiate, with cirri maturating posteriad (Fig. 7). The dorsal primordia arise within the old structures (Fig. 8 ), and fragmentation of dorsal kinety 3 [which happens in divisional morphogenesis (DE CASTRO et al., 2016) and is noticeable in interphase (PAIVA et al., 2014)] possibly occurs in very late reorganizers.
In middle-to-late reorganizers, the short streaks of basal bodies that originate between FVT primordia IV and V, viz. primordia $\mathrm{IV}_{2}$ form each a single transverse cirrus (Figs 9, 10). During the process, they produce vestigial procirri, which are resorbed (Fig. 9). However, in some specimens (Fig. 10), one of such procirri in the leftmost IV, primordium can maturate, becoming an extra postperistomal cirrus. Dorsomarginal kineties are formed right of right marginal row primordium, near its anterior end. The outer dorsomarginal kinety starts its development contiguously with the juvenile marginal cirri, then separates and moves rightwards. The paroral and endoral membranes appear differentiated, but still disposed parallel to each other, hence, the cyrtohymenid curvature and subsequent deepening of the oral cavity must occur in late reorganizers, which were not observed among the studied specimens (Fig. 10). During physiological reorganization, the distance between the macronuclear nodules is conspicuously reduced, the nodules briefly touching each other (Fig. 11). Fusion of the macronuclear nodules was not observed. At least one or two micronucleus per cell becomes ellipsoid and divides (Figs 11-14).

After reorganization, the remaining old ciliary structures are fully resorbed, except by the collar and 

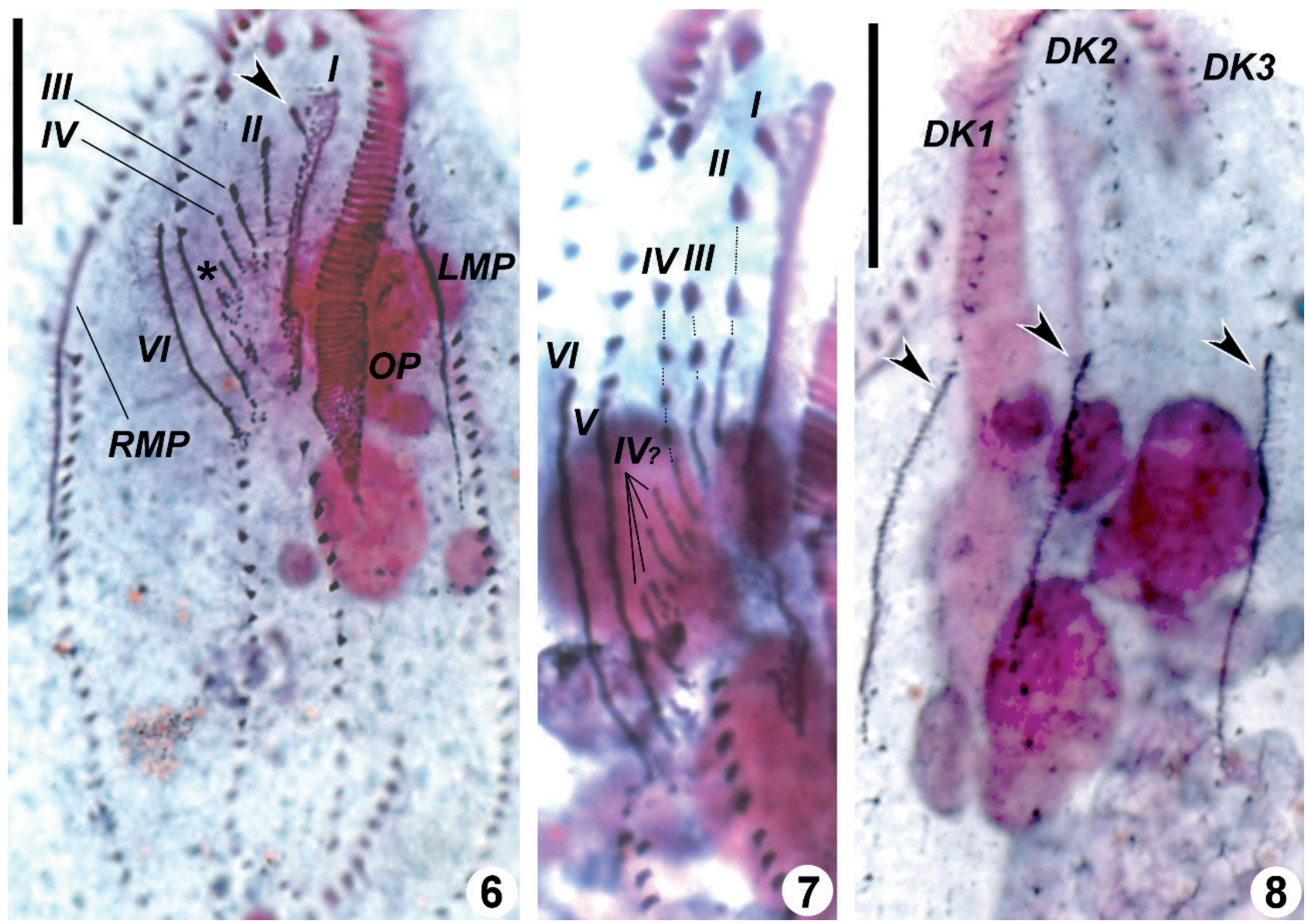

Figs 6-8. Middle reorganizers, after protargol-impregnation. Figs 6, 7. Ventral side of specimens showing primordia segregation in 6 and differentiation in 7. The arrowhead in Fig. 6 shows the left frontal cirrus differentiating from the undulating membranes primordium (I). An asterisk marks the ladderized arrangement of the short primordia $\mathrm{IV}_{\text {}}$. Fig. 8. Dorsal side showing dorsal kineties primordia (arrowheads). Fronto-ventral-transverse primordia numbered in romans. (IV , short primordia possibly related to IV; DK(n), dorsal kineties; LMP, left marginal primordium; OP, oral primordium; RMP, right marginal primordium). Scale bars $=20 \mu \mathrm{m}$.

approximately half of the lapel adoral membranelles, which are maintained after physiological reorganization. The origins of each FVT primordia and their cirral products are summarized in Tab. I.

\section{DISCUSSION}

Until now, the process of physiological reorganization in Apoamphisiella was never described. When compared to species of supposedly related genera, the reorganization in Apoamphisiella vernalis resembles that described by Jerka-DZiadosz \& Frankel (1969) for a North American population of the Paraurostyla weissei complex, viz. Paraurostyla polymicronucleata Merriman, 1937, according to Berger (1999). In both cases, the oral primordium is curved rightwards and originates de novo [vs. originates adjacently (parakinetal?) to postperistomal cirri row in the European P. weissei (WIRNSBERGER et al., 1985)]; the undulating membranes start disaggregation before fusing; about half of the membranelles of the lapel are replaced; and the two rightmost FVT primordia originate from a primordium growing within the rightmost ventral row, which then splits in two.
Another important shared feature is the participation of basal bodies originating from the oral primordium to the formation of the FVT primordia. In A. vernalis, one long streak of basal bodies extends from the anterior end of the oral primordium and merges with the disaggregating left frontoventral cirrus, resulting in an small anarchic field of basal bodies near the posterior end of III, from where primordia IV and then $\mathrm{IV}_{\text {? }}$ arise. Such long streak possibly also contributes to primordium II (Fig. 4). On the other hand, in the North American P. weissei and in Paraurostyla coronata ARORA et al., 1999, there are two or three of such streaks, which are more-or-less parallel and apparently contribute to primordia II, III and IV [see Fig. 15 in JERKADziadosz \& Frankel (1969) and Figs 23, 24 in Arora et al. (1999)]. JerKa-Dziadosz \& FranKel (1969) also reported the formation of a "bare patch" of basal bodies in the space between the anterior region of the oral primordium and the proximal termini of the three leftmost FVT primordia of the North American P. weissei. Such structure is likely associated to agglomeration of basal bodies of the above mentioned streaks originating from the oral primordium. In A. vernalis, as only one of such streak develops, a proper patch is not formed. 

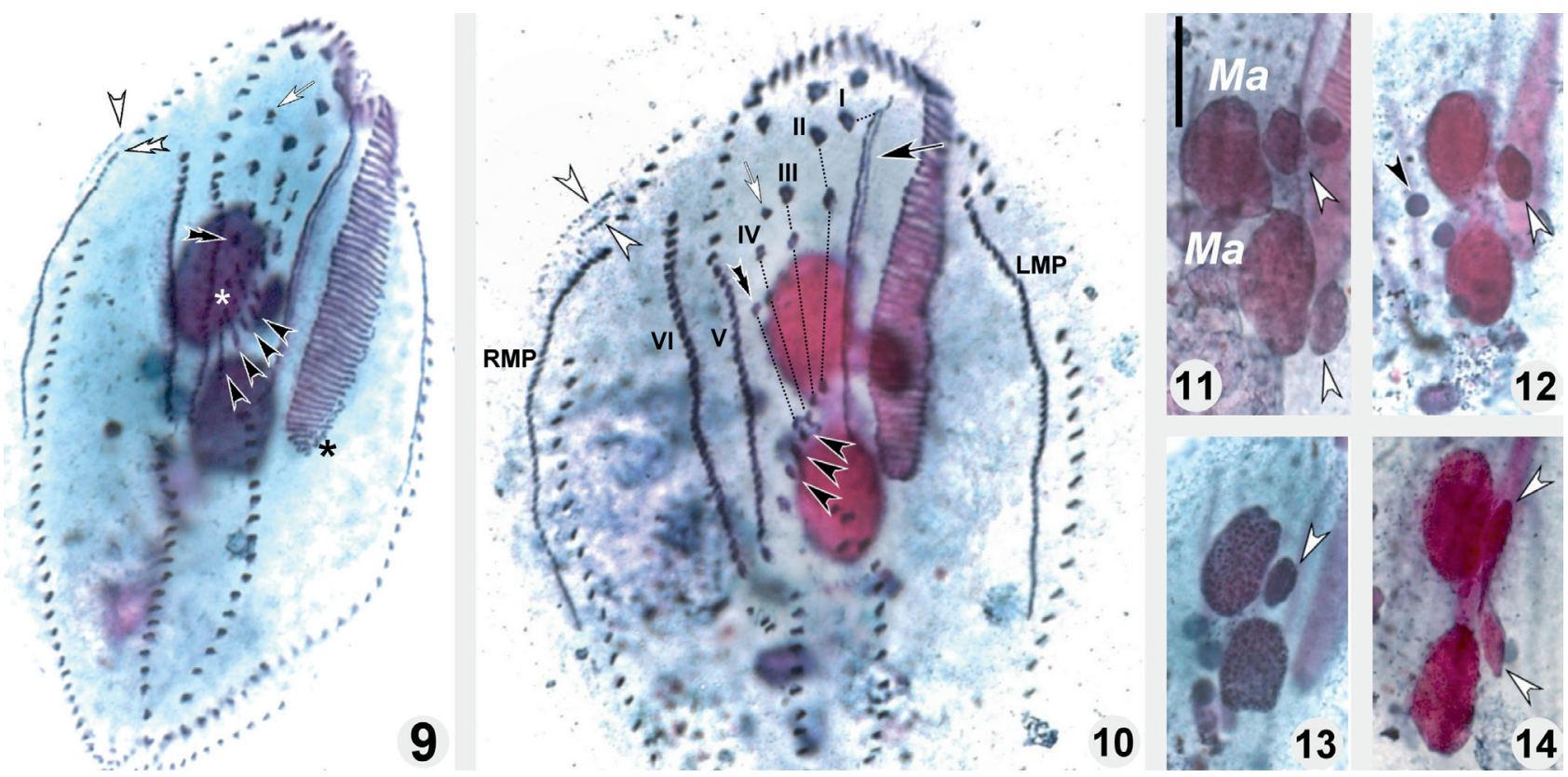

Figs 9-14. Reorganizers after protargol-impregnation. Figs 9, 10. Ventral side of middle-to-late reorganizers. Notice the formation of surplus transverse cirri (black arrowheads) by primordia $\mathrm{IV}_{\vartheta}$, the leftmost forming also a second postperistomal cirrus (double black arrowhead). White asterisk shows vestigial procirri originating from primordia $\mathrm{IV}_{n}$, which are later resorbed; black asterisk shows late differentiation of adoral membranelles; black arrow shows differentiating undulating membranes; white arrow indicates residual right frontoventral cirrus; double white arrowhead shows outer dorsomarginal kinety originating from anterior end of right marginal primordium; and white arrowheads indicate newly formed dorsomarginal kineties. Figs 11-14. Nuclear apparatus of different specimens. Notice the dividing (white arrowheads) and non-diving micronuclei (black arrowhead). Fronto-ventral-transverse primordia numbered in romans. Scale bar $=20 \mu \mathrm{m}$.

Tab. I. Origins and products of the fronto-ventral-transverse primordia of Apoamphisiella vernalis (Stokes, 1887) Berger, 2006 during physiological reorganization.

\begin{tabular}{|c|c|c|}
\hline Primordium & Origin & Product \\
\hline I & Disaggregation of undulating membranes & Left frontal cirrus + undulating membranes \\
\hline II & Disaggregation of buccal cirrus & $\begin{array}{l}\text { Middle frontal cirrus + buccal cirrus }+ \text { leftmost transverse } \\
\text { cirrus }\end{array}$ \\
\hline III & $\begin{array}{l}\text { Disaggregation of left frontoventral cirrus + basal bodies } \\
\text { from anterior end of oral primordium }\end{array}$ & $\begin{array}{l}\text { Right frontal cirrus }+ \text { left frontoventral cirrus }+ \text { transverse } \\
\text { cirrus }\end{array}$ \\
\hline IV & $\begin{array}{l}\text { Possibly associated to III + disaggregating cirri from anterior } \\
\text { end of left ventral row }\end{array}$ & $\begin{array}{l}\text { Right frontoventral cirrus }+ \text { postperistomal cirrus }+ \text { transverse } \\
\text { cirrus }\end{array}$ \\
\hline $\mathrm{IV}_{?}$ & $\begin{array}{l}\text { Possibly associated to IV + disaggregating cirri from anteri- } \\
\text { or end towards the middle of left ventral row }\end{array}$ & $\begin{array}{l}\text { Transverse cirrus, but sometimes, the leftmost anlage } \mathrm{IV}_{\text {? }} \text { pro- } \\
\text { duces also a second postperistomal cirrus. }\end{array}$ \\
\hline V & $\begin{array}{l}\text { Disaggregation of cirri slightly above equatorial region of } \\
\text { right ventral row }\end{array}$ & Left ventral row + pretransverse cirrus + transverse cirrus \\
\hline VI & $\begin{array}{l}\text { Disaggregation of cirri slightly above equatorial region of } \\
\text { right ventral row }\end{array}$ & $\begin{array}{l}\text { Right ventral row }+ \text { pretransverse cirrus }+ \text { rightmost trans- } \\
\text { verse cirrus }\end{array}$ \\
\hline
\end{tabular}

The short FVT primordia which arise between IV and $\mathrm{V}$, herein named "IV," are possibly related to IV, and may represent slightly modified replicas of it (DE CASTRO et al., 2016). Evidence of such relationship comes from the primordia behavior, which is similar to IV, viz. forming transverse cirri, but not pretransverse; and sometimes forming a postperistomal cirrus (Fig. 10). Moreover, serial repetitions of primordium IV are common in hypotrichs. They are characteristic of the urostyloids, and probably evolved independently in pattersoniellids, neokeronopsids, and perhaps also in uroleptids and rigidothrichids (FoISSNER et al., 2004; Foissner \& Stoeck, 2006, 2008; PaIVA et al., 2009), forming the so-called midventral complex (BERGER, 2006). The pattern in which primordia $I_{\text {? }}$ appear in early- to-middle reorganizers, arranged in a ladderized sequence of short basal body streaks (Figs 7, 9), recall the corresponding developmental stage of a short pattersoniellid or TerritrichaApoterritricha-like midventral complex (FoISSNER, 1987; Berger \& Foissner, 1988; Kim et al., 2014). Such structure, in A. vernalis, does not complete its development because the procirri which could maturate into midventral pairs are resorbed before differentiation. Reorganization of the marginal cirral rows and dorsal kineties had no peculiarities, occurring as in most dorsomarginalians (e.g. GRIMES \& AdLER, 1978; Jerka-DZiadosz \& FranKel, 1969; KAMra \& SAPRA, 1991; Arora et al., 1999; BLATTERER \& FoISSNER, 2003). 
During physiological reorganization, the macronucelar nodules of A. vernalis approximate in middle reorganization, briefly touching each other and then to beginning to separate in middle-to-late reorganizers. Thus, complete fusion of the nodules was not observed. However, macronuclear fusion is reported in other dorsomarginalians (e.g. ARORA et al.,1999; ZOU \& NG ,1991; BLATTERER \& FOISSNER, 2003), including the North American P. weissei, as described in Jerka-DZiadosz \& Frankel (1969). Hence, we cannot exclude the possibility of a curt fusion being overlooked because the corresponding stage could be absent among the investigated specimens. In A. vernalis, not all micronuclei seemed to divide during physiological reorganization, since the studied reorganizers exhibited only one or two dividing micronuclei (among on average five of such structures). Conversely, in the North American P. weissei, the micronuclei divide to produce a total of eight units, indicating most or all micronuclei divide, even though subsequently from reorganization, this number is reduced to about four (JERKADziadosz \& Frankel, 1969).

The data on ontogeny during physiological reorganization confirmed the presence of dorsomarginal kineties, corroborating the classification of genus Apoamphisiella within the Dorsomarginalia Berger, 2006, as mentioned in PAIVA et al. (2014). Moreover, the ontogenetic similarities with the North American population of P. weissei, plus other morphological features, such as the cyrtohymenid pattern of the undulating membranes and the morphology and arrangement of cortical granules (Grimes \& L'HERNAULT, 1978; FoISSNER, 1997; PAIVA \& SILVA-Neto, 2004; KüPPERS \& ClaPs, 2013), support the phylogenetic position of Apoamphisiella in the Cyrtohymena-Paraurostyla (BERGER, 1999; FoISSNER et al., 2004) group of dorsomarginalian hypotrichs, which was recently hypothesized by DE CASTRO et al. (2016).

Acknowledgements. This study was financed by a master degree fellowship from CAPES granted to the first author trough Programa de Pós-Graduação em Ecologia Aquática e Pesca - Universidade Federal do Pará (PPGEAP-UFPA), and funds from CNPq (Universal 485974/2013-4), FAPERJ (Biota E-26/110.022/2011) and FAPESP (2015/17856-0).

\section{REFERENCES}

Arora, S.; GuPta, R.; Kamra, K. \& SAPra, G. R. 1999. Characterization of Paraurostyla coronata sp. $\mathrm{n}$. including a comparative account of other members of the genus. Acta Protozoologica 38:133-144.

BERGER, H. 1999. Monograph of the Oxytrichidae (Ciliophora, Hypotrichia) Monographiae Biologicae 78:1-1080.

Berger, H. 2006. Monograph of the Urostyloidea (Ciliophora, Hypotricha). Monographiae Biologicae 85:1-1304.

BERGER, H. 2008. Monograph of the Amphisiellidae and Trachelostylidae (Ciliophora, Hypotricha). Monographiae Biologicae 88:1-737.

Berger, H. 2011. Monograph of the Gonostomatidae and Kahliellidae (Ciliophora, Hypotricha). Monographiae Biologicae 91:1-741.

BERger, H. \& FoIsSNER, W. 1988. Revision of Lamtostyla Buitkamp, 1977 and description of Territricha nov. gen. (Ciliophora: Hypotrichida). Zoologischer Anzeiger 220:113-134.

Berger, H. \& Foissner, W. 1997. Cladistic relationships and generic characterization of oxytrichid hypotrichs (Protozoa, Ciliophora). Archiv für Protistenkunde 148:125-155.
Blatterer, H. \& Foissner, W. 2003. Morphological and ontogenetic comparison of two populations of Parentocirrus hortualis Voss 1997 (Ciliophora, Hypotrichida). Linzer Biologische Beiträge 35:831-854.

Borror, A. C. 1979. Redefinition of the Urostylidae (Ciliophora, Hypotrichida) on the basis of morphogenetic characters. Journal of Eukaryotic Microbiology 26:544-550.

Da Silva-Neto, I. D; Paiva, T. Da S.; Dias, R. J. P.; Campos, C. J. A. \& Migotto, A. E. 2012. Redescription of Licnophora chattoni Villeneuve-Brachon, 1939 (Ciliophora, Spirotrichea), associated with Zyzzyzuswarreni Calder, 1988 (Cnidaria, Hydrozoa). European Journal of Protistology 48:48-62.

De Castro, L. A. M.; Küppers, G. C.; Fernandes, N. M.; Schlegel, M. \& PAIVA, T. DA S. 2016. Ontogeny and molecular phylogeny of Apoamphisiella vernalis reveal unclear separation between genera Apoamphisiella and Paraurostyla (Protozoa, Ciliophora, Hypotricha). PLoS One 11:e0155825.

Dembowska, W. S. 1925. Studien fiber die Regeneration von Stylonychia mytilus. Archiv für mikroskopische Anatomie und Entwicklungsmechanik 104:185-209.

DembowSKA, W. S. 1938. Körperreorganisation von Stylonychia mytilus beim Hungem. Archiv für Protistenkunde 91:89-105.

DembowsKa, W. S. 1939. Sur la reorganisation du corps de Stylonychia mytilu sen inanition. Comptes Rendus des Seances de la Societe de Biologie 130:565-567.

Dieckmann, J. 1995. An improved protargol impregnation for ciliates yielding reproducible results. European Journal of Protistology 31:372-382.

Dragesco, J. \& Dragesco-Kernéis, A. 1986. Ciliés libres de l'Afriqueintertropicale. Introduction à la connaissance et à l'étude des ciliés. Faune tropicale 26:1-559.

EIGNER, P. 1995. Divisional morphogenesis in Deviata abbrevescens nov. gen., nov. spec., Neogeneia hortualis nov. gen., nov. spec., and Kahliella simplex (Horváth) Corliss and redefinition of the Kahliellidae (Ciliophora, Hypotrichida). European Journal of Protistology 31:341366.

EIGNER, P. 1997. Evolution of morphogenetic processes in the Orthoamphisiellidae n. fam., Oxytrichidae, and Parakahliellidae n. fam., and their depiction using a computer method (Ciliophora, Hypotrichida). Journal of Eukaryotic Microbiology 44:553-573.

EIGNER, P. 1999. Comparison of divisional morphogenesis in four morphologically different clones of the genus Gonostomum and update of the natural hypotrich system (Ciliophora, Hypotrichida). European Journal of Protistology 35:34-48.

EIGNER, P. 2001. Divisional morphogenesis in Uroleptus caudatus (Stokes, 1886), and the relationship between the Urostylidae and the Parakahliellidae, Oxytrichidae, and Orthoamphisiellidae on the basis of morphogenetic processes (Ciliophora, Hypotrichida). Journal of Eukaryotic Microbiology 48:70-79.

EIGNER, P. \& FoISSNER, W. 1992. Divisional morphogenesis in Bakuella pampinaria nov.spec. and reevaluation of the classification of the urostylids (Ciliophora, Hypotrichida). European Journal of Protistology 28:460-470.

Eigner, P. \& Foissner, W. 1993. Divisional morphogenesis in Orthoamphisiella stramenticola Eigner \& Foissner, 1991 and O. grelli nov. spec. (Ciliophora, Hypotrichida). Archiv für Protistenkunde 143:337-345

Eigner, P. \& Foissner, W. 1994. Divisional morphogenesis in Amphisiellides illuvialis $\mathrm{n}$. sp., Paramphisiella caudata (Hemberger) and Hemiamphisiella terricola Foissner, and redefinition of the Amphisiellidae (Ciliophora, Hypotrichida). Journal of Eukaryotic Microbiology 41:243-261.

FLEURY, A. 1983. Example d'expression et de potentialites morphogenetiques ches des unicellulaires: le cas des hypotriches (protozoairescilies). Annales de la Station Biolologique de Besse-en-Chandesse 17:124228.

FoISSNER, W. 1987. Neue und wenigbekannte hypotriche und colpodide Ciliaten (Protozoa: Ciliophora) aus Böden und Moosen. Zoologische Beiträge 31:187-282.

FoISSNER, W. 1996. Ontogenesis in ciliated protozoa, with emphasis on stomatogenesis. In: Hausmann, K. \& BradburY, P. C. eds. Ciliates: Cells as organisms. Stuttgart, Gustav Fischer, p. 95-177. 
Foissner, W. 1997. Soil ciliates (Protozoa: Ciliophora) from evergreen rain forests of Australia, South America and Costa Rica: diversity and description of new species. Biology and Fertility of Soils 25:317-339.

Foissner, W.; Agatha, S. \& Berger, H. 2002. Soil ciliates (Protozoa, Ciliophora) from Namibia (Southwest Africa), with emphasis on two contrasting environments, the Etosha region and the Namib Desert. Denisia 5:1-1459.

Foissner, W. \& Stoeck, T. 2006. Rigidothrix goiseri nov. gen., nov. spec. (Rigidotrichidae nov. fam.), a new "flagship" ciliate from the Niger floodplain breaks the flexibility-dogma in the classification of stichotrichine spirotrichs (Ciliophora, Spirotrichea). European Journal of Protistology 42:249-267.

FoISSNER, W. \& STOECK, T. 2008. Morphology, ontogenesis and molecular phylogeny of Neokeronopsis (Afrokeronopsis) aurea nov.subgen.,nov. spec. (Ciliophora: Hypotricha), a New African flagship ciliate confirms the CEUU hypothesis. Acta Protozoologica 47:1-33.

Foissner, W.; van Der StaAy, S. Y. M.; VAN DER StaAy, G. W. M.; Hackstein, J. H. P.; Krautgartner, W. D. \& Berger, H. 2004. Reconciling classical and molecular phylogenies in the stichotrichines (Ciliophora, Spirotrichea), including new sequences from some rare species. European Journal of Protistology 40:265-281

FoIsSNeR, W. \& XU, K. 2006. Monograph of the Spathidiida (Ciliophora, Haptoria) Vol I: Protospathidiidae, Arcuospathidiidae, Apertospathulidae. Monographiae Biologicae 81:1-490.

FrontczaK-Baniewicz, M. \& Jerka-Dziadosz, M. 1992. Conjugationspecific cortical reorganization during zygocyst formation in the hypotrich ciliate Paraurostyla weissei. Acta Protozoologica 31:59-67.

Grimes, G. W. \& AdLer, J. A. 1978. Regeneration of ciliary pattem in longitudinal fragments of the hypotrichous ciliate, Stylonychia. Journal of Experimental Zoology 204:57-79.

Grimes, G. W. \& L'Hernault, S. W. 1978. The structure and morphogenesis of the ventral ciliature in Paraurostyla hymenophora. Journal of Protozoology 25:65-74.

Jerka-Dziadosz, M. 1965. Morphogenesis of ciliature in division of Urostyla weissei. Acta Protozoologica 3:345-353.

Jerka-Dziadosz, M. 1972. Cortical development in Urostyla. I. Comparative study on morphogenesis in U. cristata and U. grandis. Acta Protozoologica 10:73-100.

Jerka-Dziadosz, M. \& Frankel, J. 1969. An analysis of the formation of ciliary primordia in the hypotrich ciliate Urostyla weissei. Journal of Protozoology 16:612-637.

KAMrA, K. \& SAPRA, G. R. 1991. Formation of a transient corticotype during excystment in Coniculostomum monilata (Oxytrichidae, Hypotrichida) and its modification by reorganizations. European Journal of Protistology 27:331-342.

Kim, J. H.; VD’AČnÝ, P.; ShazıB, S. U. A. \& Shin, M. K. 2014. Morphology and molecular phylogeny of Apoterritricha lutea n. g., n. sp. (Ciliophora, Spirotrichea, Hypotrichia): a putative missing link connecting Cyrtohymena and Afrokeronopsis. Journal of Eukaryotic Microbiology 61:520-536.

KüPPERS, G. C. \& Claps, M. C. 2013. Hypotrichous ciliates (Protozoa:
Ciliophora) from a temporary pond in Argentina, with redescription of Apoamphisiella hymenophora (Stokes, 1886) Berger, 1999. Zootaxa 3626:55-76.

LYNN, D. H. 2008. The Ciliated Protozoa: Characterization, Classification, and Guide to the Literature, 3rd edn. Dordrecht, Springer. 608p.

NG, S. F. 1990. Developmental heterochrony in ciliated protozoa: overlap of asexual and sexual cycles during conjugation. Biological Reviews 65:19-101.

Paiva. T. DA S.; Dias, R. J. P. \& DA Silva.-Neto, I. D. 2014. Redescription of the Little-known Ciliate Apoamphisiella vernalis (Stokes, 1887) Berger, 2006 (Ciliophora, Hypotricha) from the Atlantic Forest, Brazil. Journal of Eukaryotic Microbiology 61:561-568.

Paiva, T. DA S.; Borges, B. do N.; Harada, M. L. \& da Silva-Neto, I. D. 2009. Comparative phylogenetic study of Stichotrichia (Alveolata: Ciliophora: Spirotrichea) based on 18S-rDNA sequences. Genetics and Molecular Research 8:223-246.

PAiva, T. DA S. \& DA Silva-NeTO, I. D. 2004. Comparative morphometric study of three species of Apoamphisiella Foissner, 1997 (Ciliophora: Hypotrichea) from Brazilian locations, including a description of Apoamphisiella foissneri sp. n. Zootaxa 505:1-26.

PAIVA, T. DA S. \& DA SiLvA-Neto I. D. 2007.Morphology and morphogenesis of Strongylidium pseudocrassum Wang and Nie, 1935, with redefinition of Strongylidium Sterki, 1878 (Protista: Ciliophora: Stichotrichia). Zootaxa 1559:31-57.

Paiva, T. DA S. \& DA Silva-Neto, I. D. 2009. Morphology and divisional morphogenesis of Nudiamphisiella interrupta Foissner, Agatha \& Berger, 2002 (Ciliophora: Stichotrichia) based on a Brazilian strain. European Journal of Protistology 45:271-280.

Siqueira-Castro, I. C. V.; Paiva, T. Da S. \& Da Silva-Neto, I. D. 2009. Morphology of Parastrongylidium estevesi comb. nov. and Deviata brasiliensis sp. nov.(Ciliophora: Stichotrichia) from a sewage treatment plant in Rio de Janeiro, Brazil. Zoologia 26:774-786.

Small, E. B. \& LynN, D.H. 1985. Phylum Ciliophora Doflein, 1901. In: Lee, J. J.; Hutner, S. H. \& Bovee, E. C. eds. An illustrated guide to the Protozoa. Lawrence, Society of Protozoologists, p. 393-575.

Stokes, A. C. 1887. Some new hypotrichous infusoria from American fresh waters. Annals and Magazine of Natural History 20:104-114.

Wallengren, H. 1900. Studier öfver ciliate infusorier. IV. Acta Universitatis Lundensis 36:1-54.

Wicklow, B. J. 1982. The Discocephalina (n. subord.): ultrastructure, morphogenesis and evolutionary implications of agroup of endemic marine interstitial hypotrichs (Ciliophora, Protozoa). Protistologica 18:299-330.

Wirnsberger, E.; Foissner, W. \& Adam, H. 1985. Morphological biometric, and morphogenetic comparison of two close related species, Stylonychia vorax and S. pustulata (Ciliophora: Oxytrichidae). Journal of Protozoology 32:261-268.

Zou, S. F. \& NG, S. F. 1991. Physiological reorganization and post-traumatic regeneration in Stylonychia mytilus: reflections on developmental constraints and the evolutionary origin of alternative modes of asexual morphogenesis. Journal of Protozoology 38:182-192. 